\title{
The Continuing Evolution of Official Statistics: Some Challenges and Opportunities
}

\author{
Steve MacFeely ${ }^{1}$
}

\begin{abstract}
As economies, societies, and environments change, official statistics evolve and develop to reflect those changes. In reaction to disruptive innovations arising from globalisation, technological advances, and cultural changes, the pace of change of official statistics will accelerate in the future. The motivation for change may also be more existential than that of the past as official statisticians consider the survival of their discipline. This article examines some of the emerging developments and questions whether they present threats or offer opportunities.
\end{abstract}

Key words: Big data; globalisation; measuring progress; statistical literacy; interoperability.

\section{Introduction}

'The only thing that is constant is change' - Heraclitus

Ever since official statistics have been compiled, they have evolved to reflect changes in economy and society. Only a few years ago, reducing respondent burden was one of the dominant issues for official statistics in Europe and was the focus of many international statistical conferences. Yet today, following the financial crash of 2008 and the subsequent economic crisis, burden is no longer the dominant issue. Now a new range of more immediate pressures are confronting official statistics. Disruptive innovations such as social media and big data, measurement challenges arising from globalisation, and the need to understand social, economic, and environmental progress, are forcing official statistics to once again adapt and evolve.

Over time official statistics have become recognised as a cornerstone of democracy, underpinning transparency and accountability. This recognition is important, as the collection and compilation of statistics are costly both to the public, who pay for them through their taxes, and to businesses because of the administrative costs of supplying data. As recompense, most nations view official statistics as a public good and disseminate them free of charge to encourage the public and businesses to use those data to support their decision making. This is sensible and in line with the United Nations Fundamental Principals of Statistics (United Nations 2014). But many users, including governments, appear to misunderstand the real cost of 'public goods', leading to the paradox that exists today where there is an expectation of higher standards of quality and precision yet an

1 United Nations Conference on Trade and Development, Geneva, Switzerland and University College Cork, College Road, Cork T12 YN60, Ireland. Email: steve.macfeely@unctad.org 
unwillingness to pay for that precision. If adequate funding is not secured, then National Statistical Institutes (NSIs) and other producers of official statistics may be forced to make compromises that will ultimately undermine the independence and quality of official statistics.

Official statistics faces many tests, and they cannot all be dealt within a single article. This article limits discussion to the challenges arising from globalisation, measuring progress, and big data. Why these and not others? The issues presented in this article have been selected owing to their importance, not only for NSIs but for governments, businesses, and citizens also: modern globalisation is complex and our understanding of it tentative at best, yet it has far-reaching implications - corporate taxation policy, trade policy including tariff and non tariff barriers, understanding international trade and value chains, offshoring and outsourcing - all with implications for World Trade Organization (WTO) negotiations, employment, and real incomes. The need for environmental sustainability and economic stability should be obvious to all. The policy implications arising from a wider concept of 'progress' have not always been as clear, but the post-2015 Sustainable Development Goals will have gone a long way to removing this ambiguity. The requirement for an integrated information system that straddles and balances the three pillars of economy, society, and environment has now been clearly articulated - this will be a huge challenge for national, regional, and international statistical organisations. The success or failure of that information system to hold governments, businesses, and peoples to account may be of profound existential importance for 'people, planet, and prosperity'. Finally, the use of big data raises weighty questions for governments, businesses, and citizens alike - not least regarding privacy, ethics, and trust. For NSIs, big data also present a dilemma as they are both a threat and an opportunity. How NSIs deal with this will be of great importance for everyone.

There are several reasons for this article: to provide a general context and illustrate or highlight some of the issues that NSIs are grappling with; to provide a brief explanation of why these issues are important, complex and not easily solved; perhaps also to provoke some debate and discussion; and finally to reassure readers that while much still remains to be done, considerable thought and work have already been dedicated to these issues. The article is presented in six sections: Sections $2-4$ deal in turn with the changing landscape arising from the emergence of new data sources, the measurement challenges posed by globalisation and measuring progress; Section 5 discusses two cross-cutting issues that stem from the challenges outlined in the first three sections, specifically the need to take statistical literacy seriously and the difficulties of moving from legacy production systems to more modern interoperable systems. The final section presents a short conclusion.

\section{A Changing Landscape}

According to Ball (2004), the etymology of the term statistics comes from the Latin term statisticum collegium, meaning 'council of state', and refers to science of the state. However, there is no shared view or agreement on when official statistics first emerged, largely reflecting differences in how statistics and official statistics are defined. What is clear is that the first set of national accounts was produced by William Petty in Ireland in 1652 during the Cromwellian occupation (Canny 1987). Ever since, statistics have served 
national administrations, whether free market or centrally planned, and have continually evolved to remain relevant. Hence Quetelet's description of statistics as "that particularly governmental science" (Mazower 2012, 100).

Today, the landscape in which official statistics operate is changing, and changing fast. In a world where our increasing day-to-day dependence on technology, social media, and electronic transactions are leaving significant 'digital footprints' in their wake, and where business models for many electronic service providers generate revenue from advertising rather than the provision of a core service, the monopoly held by official statistics for so long, namely to provide timely and high-quality statistics for free, is being challenged. The power of these new technologies should not be underestimated. Anyone doubting their reach should consider the following: there are an average 500 million tweets per day (Krikorian 2013), while Facebook has more than one billion mobile users every month (Popper 2014) the first social network to surpass one billion registered accounts (Statistica 2015). To put this in perspective, if Facebook was a country it would have the third largest population in the world after China and India. There are over eight billion snapchat views sent every day (Aslam 2015). Anyone unconvinced of the influence of social media need only look at the part it played in the 2009 UK music chart's Christmas number one, Facebook's 'Rage Against the Machine' coup (Paterson 2009), the downfall of the Philippine President Joseph Estrada (Shirky 2011), or more recently in the Arab Spring (Howard et al. 2011; Dewey et al. 2012). Of course the global influence of technology should not be overestimated either; for some technologies a sizeable 'digital divide' persists. For example, the International Telecommunication Union (2015) estimates that global Internet penetration is only $43 \%$ and global mobile broadband subscription $46 \%$, although they are as high as $78 \%$ in the developed world. Even within countries, access barriers across various social, geographic, or economic strata may lead to important cohorts being excluded, with obvious bias implications for statistics (see Struijs and Daas 2014).

The torrent of so-called 'big data' now generated as a by-product of these new digital services has been described as a "Data Deluge" (Vale 2012). But large datasets are nothing new, so what does big data mean? This is one of the challenges when discussing big data: "There is no rigorous definition of 'big data", (Mayer-Schonberger and Cukier 2013, 6). The Wikipedia definition of big data is "a collection of datasets so large and complex that it becomes difficult to process using on-hand database management tools or traditional data processing applications." Gartner, in what has become known as the three Vs, defines big data as high-volume, high-velocity, and/or high-variety information assets that demand cost-effective, innovative forms of information processing that enable enhanced insight, decision making, and process automation. The Task Team of the United Nations Economic Commission for Europe (UNECE) High-Level Group for the Modernisation of Statistical Production and Services similarly defined big data as "data sources that can be, generally, described as high volume, velocity and variety of data that demand costeffective, innovative forms of processing for enhanced insight and decision making" (UNECE 2013). In other words, big data should be huge in terms of volume (i.e., at least terabytes), have high velocity (i.e., be created in or near real-time), and be varied in type (i.e., contain structured and unstructured data and span temporal and geographic planes). 
Kitchin (2014) also argues that to be considered 'big' a dataset should be exhaustive in scope, fine-grained in resolution, relational in nature, flexible, and scalable.

The quantity of data now in existence is unknown. Here again, definitional differences complicate matters; the word 'data' means different things to different people. Consequently there are various estimates. Hilbert and Lopez (2012) estimate that 300 exabytes of data were stored in 2007 and over $90 \%$ of these were in digital format compared to only $25 \%$ in 2000 . In fact the volumes of data now being generated are so great, increasing in volume at an exponential rate, that according to Lynch (2012) "90\% of all information ever created was produced in the last two years alone"; Science Daily (2013) quotes a similar growth rate. According to Lillington 2013, "Stored digital content is doubling every two years, reaching one zettabyte [by 2012]". Kitchin (ibid.) states we are now in the 'Zettabyte Age' (an incomprehensibly large $2^{70}$ bytes). So while estimates and definitions differ, there is general consensus that the growth in data volume has been breathtaking and is set to continue. How much of these data are usable from a statistical perspective is not immediately clear, but there is sufficient evidence to suggest that adopting a closed mind would be unwise. Of growing interest is the blend of hard and soft, quantitative and qualitative data which may facilitate new and innovative types of analyses. Recent examples where usable statistics have been derived illustrate the point: The Billion Prices Project at the Sloan School at Massachusetts Institute of Technology (MIT) compiles price indices by web scraping (Cavallo 2012), Eggers (2011) developed an experimental sentiment index using Twitter, 'The Vibes of Ireland', pioneering work in Estonia generated transport and tourism statistics from mobile-phone data (Ahas and Tiru 2012), and the studies conducted by the SENSEable City Lab at MIT used Flickr to compile tourism statistics (Girardin at al. 2008). Furthermore, as Radermacher (quoted in Penneck 2014) has noted quite correctly, big data and social media do not respect national boundaries and thus offer the potential to generate new, internationally comparable statistics.

From the perspective of official statistics, the emergence of social media is a disruptive innovation. Many modern IT service providers are now disseminating statistics that to the untrained or undiscerning eye resemble official statistics, in order to attract media attention or attract browsers to their sites. Increasingly, official statistics are being forced to differentiate themselves from these new 'by-product' statistics by highlighting their relative quality, which comes from conceptual rigour, methodological quality, and transparency of metadata. As Borgman notes (2015), trusting other's data is crucial to reputation. Thus official statistics must ensure the quality of the data being produced is robust and fit for purpose. Furthermore, NSIs should be able to quantify the relative precision of their data. It will not be enough to say that the quality of data is fit for purpose; quality standards must be defined and supporting evidence must be provided to demonstrate proper standards have been achieved. If official statistics are to stand over bold comparisons, such as 'Michelin Star v Fast Food' quality (Radermacher 2013), when comparing official and unofficial statistics, then official statisticians must place greater emphasis on disseminating supporting evidence.

The emergence of new technologies and 'big data' are forcing many challenging questions to be asked. Mark Zuckerberg, the founder of Facebook, famously claimed that the age of privacy is over (Kirkpatrick 2010). Not everyone agrees. For example, one 
surmises the 39 million members of the 'Ashley Madison - Life is short, have an affair' website may be among those who disagreed when they learned the website had been hacked in 2015 with the hackers threatening to divulge their information (see Herrn 2015). There are many who have already voiced concerns over loss of privacy (see Pearson 2013; Payton and Claypoole 2015). Proposed changes to data-protection legislation in the EU to reinforce citizen's data-protection rights, including among other things the right 'to be forgotten', suggest privacy is still a real concern (European Parliament 2016). Others, such as Edward Snowden, have risked their freedom to highlight the threats to our privacy (Greenwald 2015). The increased volumes of big data being generated, and the potential to link and utilise those data, means that greater attention must be paid to data suppression techniques to ensure confidentiality can be safeguarded. This is a key tenet of the UN Fundamental Principles of Official Statistics (ibid.). But what if Zuckerberg is correct and future generations are less concerned about privacy; what are the implications for official statistics and anonymisation? If the privacy-benefit trade-off is insufficiently clear or immediate to the public, it begs the question of whether official statistics will be left in an anachronistic situation vis-à-vis the privacy of data providers.

The social media/big data space is a complex and rapidly developing area with many uncertainties, and thus an open but cautious approach is probably wise. The risk is, of course, that this is hype. Most likely it is. In 2014, Buytendijk argued that big data had passed the top of the 'Hype Cycle' and was moving towards the 'Trough of Disillusionment' and that now expectations regarding the use of big data would become more realistic. As Borgman $(2015,222)$ notes, big data are not always better data, stating: "Increasing the size of the haystack does not make the needle easier to find." Other practical questions centre on issues such as whether time series are still relevant as the pace of change increases (arguably this is already an issue for some areas experiencing rapid change, e.g., ICT statistics). Can big data be 'gamed' or manipulated by the public (remember the 2009 Facebook Christmas No.1 coup)? A growing proportion of Twitter accounts are actually 'social robots' used to influence public communication. "As few as 35 percent of Twitter followers may be real people, and as much as ten percent of activity in social networks may be generated by robotic accounts" (Borgman 2015, 131). Furthermore, Reich (2015) notes that in 2010, the top ten websites in the United States accounted for 75 percent of all page views. With such concentration comes power and the associated risks of abuse and manipulation. Will this inhibit the use of some big data as a source for compiling official statistics? Should new data streams generated from secondary data be made to conform to existing classifications (which are typically artefacts of compromise defined by the availability of data at a particular time), or will new contemporaneous ad-hoc classifications be generated? Strategic questions arise, too - for example, could/should official statisticians play a new role in the future, accrediting or certifying the quality of data derived from social media? Competition is naturally feared, but sometimes it results in a better product or service. But in a situation where official statistics must adhere to increasingly rigorous quality standards with all the inherent trade-offs between quality and timeliness, whereas 'marketing' statistics do not necessarily adhere to any known standards, it is not clear what the future holds for official statistics.

Official statistics must embrace and harness a range of technologies to survive in today's rapidly changing environment. These technologies and their owners have the 
potential to threaten the dominant role of official statistics or, more pessimistically, their existence. But if exploited, they may offer opportunities to compile or integrate and disseminate new information in new and exciting ways. In 2013, the leaders of the European Statistical System embraced the latter view in the Scheveningen Memorandum (European Statistical System Committee 2013), where they clearly saw potential for compiling official statistics from big data. For example, flow or dynamic statistics can be derived from administrative or continuous data (something that is very difficult and costly to achieve with sample-based statistics), offering the potential for more policy-relevant, outcome-based statistics. An example of where this might be very useful would be researching the real cost of innovation and testing Harford's assertion "Here's the thing about failure in innovation: it's a price worth paying" $(2012,103)$ by examining initial failure with later success by linking enterprise demography, Chief Executive Officer (CEO) attributes and histories with innovation survey microdata over time. New technologies and social media also offer an opportunity to move beyond traditional product innovation and to 'open innovate' or 'crowdsource', where the collective ingenuity of data consumers is tapped to become co-creators. Of course, the conundrum is how to leverage the wisdom of crowds in a productive and focused way when frequently they don't appear to know what they want (a dilemma that both Henry Ford and Steve Jobs noted. Henry Ford famously said 'If I had asked people what they wanted, they would have said faster horses' and Steve Jobs said 'People don't know what they want until you show it to them'). This is difficult to achieve, but it can be done as Lego's 'Designbyme' approach has demonstrated (Robertson and Breen 2013). But probably the single biggest challenge for official statisticians is managing expectations. No doubt in the years to come official statistics will experience a data revolution in which big data will play an increasingly important role. But those changes may not happen as quickly as some expect. Furthermore, it is highly unlikely that the costs of compilation will fall dramatically as a result.

\section{Globalisation}

Depending on the lens through which history is viewed (political, social, colonial, economic, biological) the beginnings of globalisation differ - see O'Rourke and Williamson (2002), Menzies (2003), Ferguson (2004), Osterhammel and Petersson (2005), and Mann (2011) for some varied perspectives. But all agree on its importance, with President Clinton describing it as the "central reality of our time" (Lewis, 2000). Taleb (2007) agrees, but warns against 'naive globalisation' which gives the appearance of stability but in fact creates interlocking fragility. In any event, international trade has existed in one form or another for centuries. Now Sturgeon (2013) argues that we need to distinguish between what he calls internationalisation and today's more complex and integrated globalisation. Sachs (2012) and Yergin (2012) draw similar distinctions in what they respectively term "new globalisation" or "the new age of globalisation".

Both Sachs and Friedman (2006) argue that changes in the geopolitical landscape, such as the collapse of the Berlin Wall in 1989, China joining the WTO and the emergence of the BRIC countries (Brazil, Russia, India, and China) in 2001 have effectively expanded the commercial or economic world. Yergin makes a similar case but also stresses the contribution of privatisation and deregulation in the 1980s, political reform in India and 
the integration of Europe. All agree that technological revolution, such as the birth of the World Wide Web in 1991 and the emergence of the digital electronic age has utterly changed the way businesses transact. Baldwin refers to this as the "second unbundling of globalisation" $(2011,4)$, where the Internet has dramatically reduced international communications and transactions costs, facilitating the financialisation of commodities and a blurring of the distinction of tradable and non tradable services. Financial integration depended on informational integration.

The reach of economic globalisation has had impacts on employment growth and loss, crisis contagion, trade policy, and protectionism. So much so that Mazower (2012) argues that globalisation has in fact become an ideology in and of itself. Stiglitz $(2002,2010)$ has highlighted the role of globalisation in rising income inequality and decline in real incomes. The preponderance of cheap goods from China and India has helped to create an artificial inflation lid across much of the western world. But for developing countries too, the benefits of economic globalisation can be mixed. Traditional measurements of the macro economy and international trade have not always made it easy to understand how economies interact or participate in global value chains. Piketty (2014) has highlighted the consequent challenges for developing countries of ensuring that their markets are not exploited or prematurely forced to liberalise. Policy makers must grapple with such issues. Official statistics must contribute to these debates and discussions in a positive rather than a limiting way. To steal a slogan commonly used about IT, statistics should be a climbing frame, not a cage.

By ignoring the impact of globalisation, official business and macroeconomic statistics may be measuring price, production, and Gross Domestic Product (GDP) incorrectly (Sturgeon 2013; Houseman et al. 2014). An analysis of Bureau of Labour Statistics price data in the US led Houseman et al. $(2010,2)$ to conclude that indices were biased as 'Price declines associated with the shift to low cost foreign suppliers generally are not captured'. This in turn may result in a miscalculation of Gross Value Added (GVA) or at least its attribution to the wrong country or region with implications for macroeconomic statistics and, in a European context, the distribution of structural and cohesion funds. Our understanding of how and where labour inputs interact within the production function may no longer be realistic or accurate. Consequently, the standard approach to calculating labour and multifactor productivity may be naïve, or worse - misleading.

Eurostat, in cooperation with the WTO, the Organisation for Economic Cooperation and Development (OECD), the United Nations Economic Commission for Europe (UNECE), the United Nations on Trade and Development (UNCTAD) and the United Nations Statistics Division (UNSD) have begun to address these issues. UNCTAD has been critically highlighting the growing importance of globalisation for many years (2005, 2008, 2012), and some of their more recent work (2015) raises questions regarding the measurement and our understanding of Foreign Direct Investment (FDI). In 2010, the OECD published their handbook Measuring Globalisation with recommendations for new indicators. The Eurostat FRIBS or Framework Regulation for Integrated Business Statistics (European Commission 2011 and 2013) and Simplification of Trade Statistics or SIMSTAT (European Commission 2012) projects, although proving contentious, are at least challenging official business and macroeconomic statisticians to question whether the existing approach is fit for purpose. UNECE established a Group of Experts to examine 
the impact of globalisation on national accounts. In 2012 they published their first guide on the impacts of this phenomenon. But many thorny issues remain to be unravelled. For example, MacFeely (2012) has queried whether 'nationality' is still a meaningful concept with regard to enterprise ownership as many large multinational enterprises (MNEs) are effectively super-national, defying geo-spatial classification. Alajääskö et al. (2011) and Sturgeon (2013) have illustrated the importance of global value chains and international sourcing, with implications for producer prices and classifications. For example, there is no agreed approach for the calculation and application of deflators. Other questions arise should a 'Business Function' classification be introduced to business statistics? Should business functions replace product classifications in some instances - perhaps to codify business costs? The pros and cons must be weighed up carefully; business functions may be easier for respondents to understand, but it is not clear whether data classified to business function can provide sufficient detail to compile national accounts and supply and use tables. These questions cut right to the heart of alignment and integration. It goes without saying that properly measuring globalisation will require a coordinated global solution. For this reason, in the spring of 2015 the Statistical Commission of the UN agreed (see Decision 46/107) to establish two expert groups to look at these and other related issues, namely an Expert Group on the Handbook for a System of Extended International and Global Accounts (EG-SEIGA) and an Inter-Secretariat Working Group on International Trade and Economic Globalization Statistics (ISWG-ITEGS).

For small, open economies like Singapore or Ireland, GVA or GDP is not a very useful or informative measure of real output or standard of living and is of particularly limited use when attempting regional comparisons (MacFeely et al. 2011). Fitzgerald (2014, 34), discussing the Irish economy, is worth quoting on this point: "problems with the standard national accounts presentation arise from the exceptional openness of the Irish economy and the related globalisation of the tradable sector of the EU economy. To better understand what is happening in Ireland today significant additional data are needed, supplementary to the national accounts, which would show the contribution of each sector of the economy to GNP." These issues are not unique to Ireland and cannot be ignored if modern business and economic statistics are to be useful to policy makers grappling with the complex realities of economic globalisation.

The implications for official statistics are clear and nontrivial. This new form of globalisation is more complex and more difficult to measure than its predecessors. There is some urgency in dealing with this issue, as the research outlined above suggests that current business statistics methodology may not properly capture the complexity and impact of globalisation. This in turn has implications for core macroeconomic indicators and the policies they inform. Apart from the challenges of measuring GVA and GDP correctly, many are questioning whether GDP is an appropriate or useful measure for the 21st century (Coyle 2014).

\section{Measuring Progress}

Following World War I, the Great Depression of the 1930s and the onset of World War II, GDP emerged from these crises and the 1944 Bretton Woods conference as the preeminent economic indicator (Dickinson 2011; Fioramonti 2013) and the ultimate measure 
of a country's overall welfare. Although a purely economic measure, GDP has frequently been used as a proxy measure for welfare. Palmer in 1966 described GDP as the "chief criterion for national welfare or progress." Steve Landefeld, Director of the United States Bureau of Economic Analysis, in 2010 similarly noted the "singular focus on GDP alone as a measure of society's welfare" (Bureau of Economic Analysis, 2010). Described by Samuelson and Nordhaus (Landefeld 2000) as one of the greatest inventions of the $20^{\text {th }}$ century, as Philipsen $(2015,237)$ notes "GDP is not just a measure of the economy. It defines the economy". But from the outset, Simon Kuznets, the economist most commonly associated with the creation of GDP, cautioned that GDP could unwittingly act as a 'statistical laundry' concealing inequality and would be an unreliable or inappropriate measure of well-being, noting "the welfare of a nation can scarcely be inferred from a measure of national income" (Kuznets 1962, 29). Stiglitz (2014) went further, saying that not only is GDP not a good measure of welfare, but "GDP is not a good measure of how well an economy is performing" and that "too much has already been sacrificed on the altar of GDP fetishism”. Nevertheless, as Talberth et al. $(2007,1)$ note, “GDP maintains its prominent role as a catchall for our collective well being".

There have been many attempts since the 1970s to challenge the primacy of GDP as the definitive measure of progress, such as: the Measure of Economic Welfare (MEW); the Total Incomes System of Accounts (TISA) or the Index of Sustainable Economic Welfare (ISEW), which was later renamed the Genuine Progress Index (GPI), and the Human Development Index (HDI); and perhaps most famously, the unfortunately titled Gross National Happiness (GNH) proposed by the King of Bhutan. The essence or spirit of these alternatives was perhaps best encapsulated by Robert F. Kennedy's reference to GDP during a 1968 campaign speech in the University of Kansas: "it measures everything in short, except that which makes life worthwhile" (Kennedy 1968).

Considering the circumstances in which GDP achieved dominance, it is ironic that it was another economic crisis, namely the financial crash of 2008 and subsequent recession, that has arguably reinvigorated attempts to develop a more wide-ranging measure of progress. The Commission on the Measurement of Economic Performance and Social Progress (better known as the Stiglitz-Sen-Fitoussi Commission) was established by the then president of France, President Sarkozy, in 2008 to determine whether a better or more comprehensive measure of economic and social progress could be established. This commission reported in 2010 (see Stiglitz et al., 2010). In 2009, the European Commission published their roadmap "Beyond GDP", which is an amalgam of 'enlarged GDP', social and environmental indicators and other measures of well-being. The Obama administration formally established the Key National Indicators Commission in 2010 to develop a comprehensive indicator system (KNIS) for the United States, which comprises over 300 key and twelve composite indicators. The following year the OECD launched their "Better Life Index" (BLI) to try and address similar questions. UN Secretary-General Ban Ki-Moon, speaking at a High Level meeting on 'Happiness and Well-being: Defining a New Economic Paradigm' in 2012, noted the importance of establishing "a Sustainable Development Index, or a set of indicators to measure progress towards sustainable development" (United Nations 2012). Working separately, the United Nations University International Human Dimensions Programme on Global Environmental Change (UNU-IHDP) in collaboration with the United Nations Environment Programme 
(UNEP) has also developed an Inclusive Wealth Index (IWI). All of these indicators Beyond GDP, the KNIS, the BLI, the SDI, and the IWI - have adopted a dashboard approach rather than trying to develop a single aggregate index. This reflects the complexity of the modern world, and illustrates the communications and branding challenge ahead. It also reflects the wider scope of issues that now are included under the 'progress' umbrella: environmental sustainability; economic stability and sustainability; and social health, satisfaction, and general well-being.

From a cultural perspective, GDP, like $\mathrm{E}=\mathrm{MC}^{2}$, is a somewhat magical number with a celebrity status that transcends the number itself. At some superficial level these are two of the most recognised terms or concepts in the world, yet very few really understand what they mean. Chambers $(1989,128)$ discussing Einstein's General Theory of Relativity, neatly captured this irony: "the pathetic paradox that Einstein's discoveries, the greatest triumph of reasoning mind on record, are accepted by most people on faith". The same could arguably be said of Kuznets and GDP. The challenge for official statistics is how to supplement GDP, a number with considerable cultural authority, with another number or index that is complex enough to incorporate resource depletion, environmental degradation, well-being, social inequality, and economic performance, but is simple enough to be accepted as the new number. The public are receptive but confused; they intuitively understand they are caught in a 'Growth Trap' where progress is dependent on continual consumption and unsustainable replacement (Slade 2006). This situation prompted Richard Layard (2011) to quip "Anyone who believes in indefinite growth on a physically finite planet is either mad, or an economist". They also intuitively understand that while GDP is imperfect, it is at least, for the moment, the agreed barometer of economic progress. It has also been argued that GDP is an out of date concept, "a relic of a period dominated by manufacturing" (The Economist 2016, 22) struggling to capture the impact of myriad intangible innovations.

The abundance of rival indicators that have arisen in recent years to challenge the hegemony of GDP poses a problem for official statistics and potentially risks a loss of credibility. Ironically, the glut of alternatives developed to supplement GDP has only confused the public, cementing the dominant position enjoyed by GDP. So while many of these new indicators may in fact represent real technical progress, their sheer number can also be viewed as a metric of failure. There is an opportunity for official statistics to show leadership in this space and agree a definitive approach. This is of course easier said than done - many institutions and countries have invested time and energy in developing their own bespoke set. Any definitive dashboard must agree on how to address resource depletion, environmental degradation, climate change, social inequality, and sustainable economic progress. The United Nations Agenda 2030 explicitly calls for the development of "measurements of progress on sustainable development that complement GDP" (Goal 17.19), but it is noteworthy that the indicator framework agreed at the $47^{\text {th }}$ United Nations Statistical Commission in March 2016 did not propose any indicators addressing this issue (United Nations Statistical Commission 2016) "Perhaps this is because there has been little consensus on a suitable replacement. Perhaps, more fundamentally, it is that there is even less consensus on how well being should really be measured and if quantitative measurements can be made at all" (Talberth et al. ibid). Thus finding an indicator (or a limited set of agreed indicators) that is not so simple that it ignores the negative 
externalities of production but not so complex that it is incomprehensible to users is a high-wire act. At first glance, this seems an impossible task, as the messages from dashboards are often hard to interpret, but the "Business Cycle Tracer" compiled by Statistics Netherlands provides an excellent example of how complexity can be presented in a digestible format by mapping the trajectory of fifteen indicators on to a $2 \times 2$ matrix (above/below trend and decreased/increased). There are arguments too for a single composite measure, despite the trade-offs and weighting challenges, as the media and public tend to like definitive answers (even if oversimplified). Whatever measure or measures are selected, they must be sufficiently authoritative and scientific to compete with GDP. This means moving away from terms like 'happiness' which do not translate directly or well from Eastern culture and lead many to misunderstand the concept being proposed.

\section{Two Cross-Cutting Issues}

The challenges outlined above can be broken down into many subchallenges. In this section, two particular cross-cutting issues are briefly discussed: statistical literacy and the modernisation of the compilation process. These issues have been selected as they are of relevance to everything discussed so far.

\subsection{Statistical Literacy}

Statistics and general numeracy are increasingly becoming a necessary competency in modern life and the lingua franca of day-to-day transactions. Hence, improving statistical literacy is essential if future economies are to function efficiently and if citizens are to actively participate in and contribute to society. Producers of official statistics must take this matter seriously and consider their role in education more actively.

Arguably NSIs have an obligation to address this important challenge. If the public and the business community are insufficiently statistically literate to use statistics or distinguish between fact and comment, then everything NSIs have produced has been for nought. In a world where perhaps there are too many data (without question, too much comment is being portrayed as data or fact), users are increasingly confused and may select inappropriate data with which to inform themselves or upon which base their decisions. As societies and economies become more globalised and complex, official statistics, in order to properly measure social and economic transactions, are unavoidably becoming more complex in parallel.

To many, statistical results are not clear or intuitive. In fact, to many, results often appear improbable, impenetrable or unrealistic. In many cases this confusion arises because users do not read or understand the metadata, the background notes or the small print. Too often, users think they understand the data and their implications when clearly they do not. This situation may arise when a commonplace term means something quite different to a statistician than to the man on the street - for an example of this, consider how a typical householder and a national accountant might define or describe 'household savings'. But in other cases, NSIs must accept that the message is not always as clear as it could be. No doubt this contributes to the perception that statistics are less than useful and 
helps sustain the popularity of quips like Mark Twain's famous 'Lies, damned lies, and statistics'.

The day-to-day abuse and misuse of statistics may be inadvertent or deliberate, but either way, they pose a challenge for official statistics. Indiscriminate and often sensationalist media are the shop window through which official statistics are viewed. If these statistics are not presented properly, then the product and brand are tarnished. Users with little time, already confused and bewildered by the massive volume of statistics available, may find themselves drawn to statistics that are visually appealing or appear simple or straightforward. Users rarely see complex concepts or methodologies as attractive. The data deluge has created new or supplementary roles or responsibilities for national and international statistical institutes; we must repackage our products to make them more user friendly without compromising their integral quality and educate users so that they are better able to select and use appropriate data to suit their purposes. Thus brand building and education are intertwined and must become key objectives for NSIs in the future. In doing so, NSIs will provide a better service to their customers and protect their market position. On the statistical literacy side, there are already some good examples from which to learn: the New Zealand National Certificate in Official Statistics, the Irish Professional Diploma in Official Statistics for Policy Evaluation, the International Association of Statistical Education (IASE) International Statistical Literacy Project and the European Masters Programme in Official Statistics (EMOS). The UNECE (2012) has also published a guide for compilers on improving statistical literacy as part of their 'Making Data Meaningful' series. Equally, on the more promotional side, there are also some interesting examples from around the world of how this can be done: the Australian Bureau of Statistics has developed some highly creative and innovative interactive promotional tools, such as their 'Run that Town' app, as has the Central Bureau of Statistics in the Netherlands with their 'On a normal day' movie.

In tandem with promotion, NSIs must improve the accessibility of products; this means making it easier to find and use the data and as well as making it easier and more intuitive for non specialist users to understand those data. UNECE (2009a; 2009b; 2011) has published some useful guides on communicating and presenting statistics. There are also examples of how this might be done at country level: Statistics Finland and the Central Statistics Office in Ireland have used competitions to crowdsource ideas for statistical apps that encourage the use of statistics. Greater thought must also be given to ways to encourage businesses to respond and engage with statistics, perhaps through tailored or bespoke analyses to demonstrate the usefulness of the data to which they are contributing.

\subsection{Building Interoperability}

As already noted, it would appear that official statistics can learn some valuable lessons from Lego, who deliberately set out to develop a fully integrated 'system of play' (Robertson and Breen 2013). Since 1958, over 400 billion Lego bricks have been produced, an estimated 62 pieces for every person on earth (Diaz 2008) - all of these bricks can be connected. At first glance, this seems the natural analogy for what official statistics as a discipline needs to achieve. After all, official statistics enjoys the advantage of working from more or less conceptually consistent frameworks and classification 
systems that have been carefully developed over time. A good example of this are the recently developed Tourism Satellite Accounts (UNSD 2010) that are conceptually consistent with the Balance of Payments and International Investment Position Manual, more commonly known as BPM6 (International Monetary Fund 2009) and UN System of National Accounts (UNSD 2009). The UN System of Environmental-Economic Accounting (United Nations 2014) is another example. This consistency across products is critical as it, like Lego, should offer the potential to develop an expandable, integrated data and analytical system. To some extent it already does, but several factors inhibit full scalability and interoperability; different IT and data infrastructures (MacFeely and Dunne 2014) and different administrative production systems. International statistical organisations promote standard approaches to production, such as the UNECE Generic Statistics Business Process Model and Generic Statistical Information Model. Considerable collaborative time and effort is also being devoted to examine how shared 'plug and play' systems can be developed (Museux 2012; Vale 2013).

From a modernisation perspective, the challenge for official statistics is how to move from existing legacy systems to a more streamlined vision of official statistics without wasting years of investment or compromising national mandates and structures. This challenge has been likened to rebuilding an airplane while in flight. Official statistics already employ a multitude of production systems around the world that unlike Lego cannot be easily joined up or connected, so it is not clear how to make the transition. Useful lessons can be taken from the evolution of freight containers. In the 1950s Malcolm McClean introduced the concept of the 'intermodal container' which eventually realised the international standardisation of shipping containers, allowing ship, road and rail transport to interconnect seamlessly (Levinson 2006). The transition from multiple freight and container systems to the ubiquitous 'twenty foot equivalent unit' container took years to implement and in the process there were winners (Singapore, New Jersey, and Felixstowe) and losers (Manhattan), but today the intermodal container has completely transformed the transport of merchandised goods and the face of international trade. Arguably the multimodal container is a better analogy for statistics than Lego - Lego was designed as an interoperable system from the very beginning, whereas as several models of official statistics have evolved independently and now require consolidation, like containers did. In many respects, current modernisation initiatives can be summarised as attempts to de-silo legacy production systems. However, in most cases, these attempts to de-silo are done within the constraints of national silos, that is, each country is attempting to de-silo independently. This should be no surprise, as this makes sense for a host of practical and strategic reasons. However, the globalised nature of many big data and the need to adopt a more integrated approach to measure globalisation suggests a more ambitious approach could be considered (for some fields at least). For some domains, the most logical and efficient approach may be to centralise statistical production in a single centre rather than replicating production many times over in individual countries. Obviously, this would not work for all domains, but where feasible, it would remove the need for 'plug and play' as the methodology would only be applied once with a better chance of international comparability.

One of great advantages enjoyed by official statistics is the high level of cooperation and, by and large, shared objectives between national and international statistical agencies 
around the world. Viewed as a whole entity, the capacity and global reach of the international statistical system is similar to that of a giant and powerful multinational enterprise. The challenge is to harness that power, so that the challenges of globalisation, measuring progress and levering big data are overcome without undermining valid national concerns. Moving to a continuous, expandable, fully integrated data and analytical 'system' rather than a disparate collection of statistical products or statistical compilers will take time and leadership, but if done sensibly will strengthen the official statistics brand.

\section{Conclusion}

Ever since official statistics have been compiled, they have adapted to economic, political, societal, and environmental events to remain relevant. This process of evolution continues today, albeit at an accelerating pace. This article has outlined three key issues for official statistics that will force further adaptation in the coming years. The issues of understanding and mapping globalisation, measuring progress, and harnessing big data and integrating them with more traditional sources are all complex in that they are conceptually knotty but also in that they all simultaneously present both threats and opportunities.

On the face of it, globalisation, progress or welfare and big data all seem like very disparate issues, and of course they are. Nevertheless there are some underlying themes or approaches that are common across all of them. Two cross-cutting themes were highlighted to illustrate this. For example, the importance of improved statistical literacy will be important for understanding all aspects of statistics, whether globalisation, welfare, or big data. The modernisation process too will have an impact on coordinating the improvement of quality of macroeconomic and business statistics, on environmental statistics, on well-being and on the integration of big data into day-to-day production.

The need for an improved understanding of globalisation has been recognised by the United Nations and NSIs; the UN Statistical Commission established two new working groups in 2015 to address these issues specifically. This is critical as global markets and financial integration facilitate global risks and contagion. Clear direction on how to reach a consensus approach for the measurement of progress is less evident and is now more urgent in the context of UN Agenda 2030. One of the complications around progress is that several disparate issues, including sustainable development and well-being, have been bundled under one broad umbrella. Furthermore each of these issues is individually complex and multidimensional. So as already noted, whatever the agreed indicators, they must be sophisticated enough to encompass issues of sustainability, inequality and welfare but straightforward enough to compete with the apparent simplicity of GDP.

Change always presents threats and offers opportunities. The challenge is to identify and mitigate the threats while seizing the opportunities. To do this, NSIs and producers of official statistics need to identify where they enjoy a comparative advantage and play to those strengths. Arguably, transparency, impartiality and political independence are among these strengths. These attributes are central to democracy and public accountability and their importance should not be underestimated but rather highlighted at every opportunity. Despite the abundance of competing information available today, the 
justification or arguments in support of official statistics have never been stronger. While the need for impartial evidence-informed policy formulation and evaluation is implicitly understood, as is the importance of statistics, compiled independently of ideology or political interference, to democratic accountability, this can easily be forgotten by the public and politicians when faced with budgetary pressures. Official statistics, as a public good, must be the bulwark against the 'asymmetries of information' that Stiglitz (2002) has railed against or the uninformed debates that Piketty (2014, p. 2-3) has described as dialogues of the deaf which are 'based on an abundance of prejudice and a paucity of fact'. The Data Revolution report "A World that Counts" has also highlighted the importance of access to data, even suggesting that uneven access to data might be considered a new frontier of inequality (Independent Expert Advisory Group on a Data Revolution for Sustainable Development 2014). Of course, the real high-wire act will be to explain our increasingly complex world in ever simpler terms.

\section{References}

Ahas, R. and M. Tiru. 2012. "Passive Anonymous Mobile Positioning Data for Tourism Statistics." Paper presented at the $11^{\text {th }}$ Global Forum on Tourism Statistics, Reykjavík, 14-16 November 2012.

Alajääskö, P., P. Nielsen, S. Rikama, and J. Sisto. 2011. "Global Value Chains International Sourcing to China and India." Available at: http://ec.europa.eu/eurostat/ statistics-explained/index.php/Archive:Global_value_chains_-_international_ sourcing_to_China_and_India (accessed 26 September, 2016).

Aslam, S. 2015. "Snapchat by the Numbers: Stats, Demographics and Fun Facts", Omnicore, October 7, 2015. Available at: http://www.omnicoreagency.com/snapchatstatistics/ (accessed 26 September, 2016).

Baldwin, R. 2011. " $21^{\text {st }}$ Century Regionalism: Filling the Gap Between $21^{\text {st }}$ Century Trade and $20^{\text {th }}$ Century Trade Rules." World Trade Organisation, Staff Working Paper ERSD-2011-08. Available at: https://www.wto.org/english/res_e/reser_e/ ersd201108_e.pdf (accessed 25 April, 2015).

Ball, P. 2004. Critical Mass: How One Thing Leads to Another. London: Arrow Books. Borgman, C.L. 2015. Big Data, Little Data, No Data - Scholarship in the Networked World. Cambridge, MA: MIT Press.

Bureau of Economic Analysis. 2010. The Economist Debates: GDP, April 20, 2010, Available at: https://www.bea.gov/about/pdf/Newsclips_GDP_group.pdf (accessed 26 September, 2016).

Buytendijk, F. 2014. "Hype Cycle for Big Data, 2014." Gartner. Available at: https:// www.gartner.com/doc/2814517/hype-cycle-big-data- (accessed 11 August, 2015).

Canny, N. 1987. From Reformation to Resistance: Ireland, 1534 - 1660. Dublin: Helicon Press.

Cavallo, A. 2012. "Online and Official Price Indexes: Measuring Argentina's Inflation." Journal of Monetary Economics 60: 152-165. Doi: http://dx.doi.org/10.1016/ j.jmoneco.2012.10.002.

Chambers, W. 1989. Ghosts on the Roof - Selected Journalism of Whitaker Chambers 1931 - 1959. Washington, D.C: Regnery Publishing. 
Coyle, D. 2014. GDP: A Brief but Affectionate History. Princeton: Princeton University Press.

Dewey, T., J. Kaden, M. Marks, S. Matsushima, and B. Zhu. 2012. “The Impact of Social Media on Social Unrest in the Arab Spring." Final Report prepared for the Defense Intelligence Agency, Stanford University. Available at: http://stage-ips.stanford.edu/ sites/default/files/shared/2012\%20Practicum\%20Policy\%20Brief\%20SocialMedia.pdf (accessed 28 March, 2014).

Diaz, J. 2008. "Everything You Always Wanted to Know About Lego.” Available at: http://lego.gizmodo.com/5019797/everything-you-always-wanted-to-know-about-lego (accessed 26 September, 2016).

Dickinson, E. 2011. "GDP: A Brief History - One Stat to Rule Them All.” Foreign Policy, January-February 2011. Available at: http://foreignpolicy.com/2011/01/03/ gdp-a-brief-history/ (accessed 26 September, 2016).

Dunning, J.H. 2005. "More - Yet More - On Globalization." Transnational Corporations Vol. 14, No. 2, August 2005 (UNCTAD/ITE/IIT/2005/5). Available at: http://unctad. org/en/Docs/iteiit20055a5_en.pdf (accessed 26 September, 2016).

Eggers, J. 2011. "Social Media Like Twitter and Facebook Can Influence Statistics." Paper presented at the $2^{\text {nd }}$ CSO Administrative Data Seminar, Dublin Castle, 29 September 2011. Available at: http://www.cso.ie/en/newsandevents/eventsconferencesseminars/administrativedataseminars/2ndadministrativedataseminar/ (accessed $21 \mathrm{Feb}$ ruary, 2014).

European Commission. 2011. "Business \& Price Statistics - A Strategic Approach for the Coming Years." Paper presented by Eurostat to the Business Statistics Directors Group, Doc. BSDG June 2011_4_1.

European Commission. 2012. "SIMSTAT Project for Exchange of Micro-Data on EUintra Trade." Paper presented by Eurostat to the Business Statistics Directors Group, Doc. BSDG June 2012_16.

European Commission. 2013. "Framework Regulation for Integrating Business Statistics." Available at: http://ec.europa.eu/smart-regulation/impact/planned_ia/docs/2012 estat_011_business_statistics_en.pdf (accessed 26 September, 2016).

European Parliament. 2015. "European Parliament News - Q\&A: new EU rules on data protection put the citizen back in the driving seat" Available at: http://www.europarl. europa.eu/news/en/news-room/20160413BKG22980/qa-new-eu-rules-on-dataprotection-put-the-citizen-back-in-the-driving-seat (accessed 26 September, 2016).

European Statistical System Committee. 2013. "Scheveningen Memorandum - Big Data and Official Statistics", adopted 27 September 2013. Luxembourg. Available at: http:// ec.europa.eu/eurostat/documents/42577/43315/Scheveningen-memorandum-27-09-13 (accessed 31 March, 2016).

Ferguson, N. 2004. Empire: How Britain Made the Modern World. London: Penguin Books.

Fioramonti, L. 2013. Gross Domestic Problem: The Politics Behind the World's Most Powerful Number. London: Zed Books.

FitzGerald, J. 2014. "Additional Data Needed to Understand Developments in the Economy." Quarterly Economic Commentary 2014: 34-25. 
Friedman, T. 2006. The World is Flat: The Globalized World in the Twenty-First Century. London: Penguin Books.

Girardin, F., F. Dal Fiore, C. Ratti, and J. Blat. 2008. "Leveraging Explicitly Disclosed Location Information to Understand Tourism Dynamics: A Case Study." Journal of Location Based Services 2: 41-56.

Greenwald, G. 2015. No Place to Hide: Edward Snowden, the NSA and the Surveillance State. UK: Penguin Books.

Harford, D. 2012. Adapt: Why Success Always Starts with Failure. London: Abacus.

Hern, A. 2015. "Infidelity Site Ashley Madison Hacked as Attackers Demand Total Shutdown." The Guardian, 20 July 2015. Available at: http://www.theguardian.com/ technology/2015/jul/20/ashley-madison-hacked-cheating-site-total-shutdown (accessed 20 July, 2015).

Hilbert, M. and P. Lopez. 2012. "How to Measure the World's Technological Capacity to Store, Communicate and Compute Information." International Journal of Communication 6: 956-979.

Houseman, S.N., C.J. Kurz, P. Lengermann, and B.R. Mandel. 2010. “Offshoring Bias in U.S. Manufacturing: Implications for Productivity and Value Added." Board of Governors of the Federal Reserve System, International Finance Discussion Papers, Number 1007, September 2010. Available at: http://www.federalreserve.gov/pubs/ifdp/ 2010/1007/ifdp1007.pdf (accessed 26 September, 2016).

Houseman, S.N., T.J. Bartik, and T.J. Sturgeon. 2014. "Measuring Manufacturing: How the Computer and Semiconductor Industries Affect the Numbers and Perceptions." Upjohn Institute Working Paper 14-209. Available at: http://research.upjohn.org/cgi/ viewcontent.cgi?article=1226\&context=up_workingpapers (accessed 26 September, 2016).

Howard, P.N., A. Duffy, D. Freelon, M. Hussain, W. Mari, and M. Mazaid. 2011. "Opening Closed Regimes: What Was the Role of Social Media During the Arab Spring?" Working Paper No.1, Project on Information Technology \& Political Islam (PITPI). Available at: http://philhoward.org/opening-closed-regimes-what-was-therole-of-social-media-during-the-arab-spring/ (accessed 28 March, 2014).

Independent Expert Advisory Group on a Data Revolution for Sustainable Development. 2014. "A World that Counts - Mobilising the Data Revolution for Sustainable Development." Available at: http://www.undatarevolution.org/wp-content/uploads/ 2014/12/A-World-That-Counts2.pdf (accessed 30 March, 2016).

International Monetary Fund. 2009. "Balance of Payments and International Investment Position Manual $-6^{\text {th }}$ Edition." Washington, D.C. Available at: https://www.imf.org/ external/pubs/ft/bop/2007/pdf/bpm6.pdf (accessed 11 February, 2014).

International Telecommunication Union. 2015. "ICT Facts \& Figures: The World in 2015." Available at: http://www.itu.int/en/ITU-D/Statistics/Documents/facts/ ICTFactsFigures2015.pdf (accessed 6 January, 2016).

Kennedy, R. 1968. 'Remarks at the University of Kansas, March 18, 1968'. John F. Kennedy Library, Presidential Library and Museum. Available at: https://www. jfklibrary.org/Research/Research-Aids/Ready-Reference/RFK-Speeches/Remarks-ofRobert-F-Kennedy-at-the-University-of-Kansas-March-18-1968.aspx (accessed 26 September, 2016). 
Kirkpatrick, M. 2010. "Facebook's Zuckerberg Says the Age of Privacy is Over." Readwrite, 9 January 2010. Available at: http://readwrite.com/2010/01/09/facebooks_ zuckerberg_says_the_age_of_privacy_is_ov (accessed 9 January, 2010).

Kitchin, R. 2014. The Data Revolution: Big Data, Open Data, Data Infrastructures and their consequences. London: Sage Publications Ltd.

Krikorian, R. 2013. "New Tweets per Second Record, and How!" Engineering Blog. Available at: https://blog.twitter.com/2013/new-tweets-per-second-record-and-how (accessed 26 September, 2016).

Kuznets, S. 1962. "How to Judge Quality." New Republic 1962 issue, October 2029-31. Available at: http://www.unz.org/Pub/NewRepublic-1962oct20-00029 (accessed 26 September, 2016).

Landefeld, S.J. 2000. "GDP: One of the Great Inventions of the 20th Century." BEA Survey of Current Business, January 2000. Available at: http://www.bea.gov/scb/pdf/ BEAWIDE/2000/0100od.pdf (accessed 26 September, 2016).

Layard, R. 2011. 'Happiness: New Lessons' in interview with Andrew Marr. Available at: https://www.youtube.com/watch?v=4VkQsL73SgE (accessed 26 September, 2016).

Levinson, M. 2006. The Box: How the Shipping Container Made the World Smaller and the World Bigger. Princeton: Princeton University Press.

Lewis, N.A. 2000. "The China Trade Wrangle: The Clinton Speech; Seeing Threats Beyond Arms, President Urges Cooperation." New York Times, U.S. edition, 8 May 2000. Available at: http://www.nytimes.com/2000/05/18/world/china-trade-wrangleclinton-speech-seeing-threats-beyond-arms-president-urges.html (accessed 30 March, 2016).

Lillington, K. 2013. "Big Data is Watching You." Quoted in article by K. Lillington Irish Times: Weekend Review, 27 April 2013.

Lynch, M. 2012. "Data Wars: Unlocking the Information Goldmine." BBC News, 12 April 2012. Available at: www.bbc.co.uk/news/business-17682304 (accessed 26 September, 2016).

MacFeely, S., R. Moloney, and M. Kenneally. 2011. "A Study of the NUTS 2 Regions Using Input-Output Analysis." Journal of the Statistical and Social Inquiry Society of Ireland XL: $60-115$.

MacFeely, S. 2012. "Reflections on Developing a Measurement Framework for Economic Globalisation." Paper presented at the Eurostat Workshop on Global Value Chains and Economic Globalisation, Luxembourg, 9 \& 10 October 2012.

MacFeely, S. and J. Dunne. 2014. "Joining Up Public Sector Information: The Rationale for a National Data Infrastructure." Administration 61: 93-107.

Mann, C.C. 2011. 1493: How Europe's Discovery of the Americas Revolutionised Trade, Ecology and Life on Earth. London: Granta Books.

Mayer-Schonberger, V. and K. Cukier. 2013. "Big Data: A Revolution That Will Transform How We Live, Work and Think." London: John Murray.

Mazower, M. 2012. Governing the World - The History of the Idea. London: Allen Lane. Menzies, G. 2003. 1421: The Year China Discovered America. New York: Harper Collins Publications.

Museux, J.M., N. Hilbert, and G. Pongas. 2012. "Implementation of the ESS Joint Strategy: The Development and Promotion of the Plug and Play Concept as an 
Architecture Model." Paper presented at Meeting on the Management of Statistical Information Systems (MSIS 2012), Washington, DC, 21-23 May 2012. Available at: https://www.unece.org/fileadmin/DAM/stats/documents/ece/ces/ge.50/2012/ presentations/Topic_1_07_Eurostat.pdf (accessed 26 September, 2016).

Organisation for Economic Cooperation and Development. 2010. "Measuring Globalisation: OECD Economic Globalisation Indicators 2010."

Osterhammel, J. and N.P. Petersson. 2005. Globalisation: A Short History. Princeton: Princeton University Press.

O’Rourke, K.H. and J.G. Williamson. 2002. "When Did Globalisation Begin?" European Review of Economic History 6: 23-50.

Palmer, E.Z. 1966. The Meaning and Measurement of the National Income. Lincoln, NE: University of Nebraska Press.

Paterson, C. 2009. "Rage Against the Machine Beat X Factor Winner in Charts." BBC News, 20 December 2009. Available at: http://news.bbc.co.uk/2/hi/8423340.stm (accessed 15 January, 2013).

Payton, T. and T. Claypoole. 2015. Privacy in the Age of Big Data - Recognising the Threats Defending Your Rights and Protecting Your Family. Lanham, MD: Rowman \& Littlefield.

Pearson, E. 2013. "Growing Up Digital.” Paper presented at the Big Data and Statistics New Zealand Seminar, Wellington, 24 May 2013. Available at: http://statisphere.govt. nz/seminars-training-forums/official-statistics-seminar-series/archived-presentations/ big-data.aspx (accessed 9 September, 2013).

Penneck, S. 2014. "New Challenges Facing Official Statistics." Statistical Journal of the IAOS 30: 3-16.

Philipsen, D. 2015. The Little Big Number - How GDP Came to Rule the World and What to Do About It. Princeton, NJ: Princeton University Press.

Piketty, T. 2014. Capital in the Twenty-First Century. Cambridge, MA: The Belknap Press of Harvard University Press.

Popper, B. 2014. "Facebook Now has More Than a Billion Mobile Users Every Month." The Verge, 23 April 2014. Available at: http://www.theverge.com/2014/4/23/5644740/ facebook-q1-2014-earnings (accessed 23 April, 2014).

Radermacher, W. 2013. "The European Statistics Code of Practice as a Pillar to Strengthen Public Trust and Enhance Quality in Official Statistics." Journal of the Statistical and Social Inquiry Society of Ireland 43: 27-33.

Reich, R. 2015. Saving Capitalism: For the Many, Not the Few. London: Icon Books Ltd.

Robertson, D. and B. Breen. 2013. Brick by Brick - How Lego Rewrote the Rules of Innovation. London: Random House.

Sachs, J. 2012. The Price of Civilization: Reawakening Virtue and Prosperity After the Economic Fall. London: Vintage, Random House.

Science Daily. 2013. "Big Data, for Better or Worse: 90\% of World's Data Generated over Last Two Years.” 22 May 2013. Available at: https://www.sciencedaily.com/ releases/2013/05/130522085217.htm (accessed 22 May, 2013).

Shirky, C. 2011. "The Political Power of Social Media: Technology, the Public Sphere, and Political Change.” Foreign Affairs January/February Issue 2011. Available at: 
https://www.foreignaffairs.com/articles/2010-12-20/political-power-social-media (accessed 11 February, 2014).

Slade, G. 2006. Made to Break: Technology and obsolescence in America. Cambridge, MA: Harvard University Press.

Statistica. 2015. "Leading Social Networks Worldwide as of August 2015, ranked by Number of Active Users (in Millions)." Statistica - the Statistics Portal. Available at: http://www.statista.com/statistics/272014/global-social-networks-ranked-by-numberof-users/ (accessed 9 November, 2015).

Stiglitz, J.E. 2002. Globalisation and its Discontents. London: Penguin Books.

Stiglitz, J.E. 2010. Freefall: Free Markets and the Sinking of the Global Economy. London: Allen Lane.

Stiglitz, J.E., A. Sen, and J.P. Fitoussi. 2010. Report by the Commission on the Measurement of Economic Performance and Social Progress. Available at: http://www.cfr. org/world/report-commission-measurement-economic-performance-social-progress/ p22847 (accessed 7 March, 2013).

Stiglitz, J.E. 2014. “America's GDP Fetishism is a Rare Luxury in an Age of Vulnerability - Traditional Measures Seem More Abstract Than Ever as They Fail to Recognise the Struggles of Wage-Earners in the Real World." The Guardian, 13 October 2014. Available at: http://www.theguardian.com/business/2014/oct/13/gdp-fetishism-luxuryvulnerability-economic-measures (accessed 30 March, 2016).

Struijs, P. and P. Daas. 2014. "Quality Approaches to Big Data in Official Statistics." Available at: http://www.pietdaas.nl/beta/pubs/pubs/Q2014_session_33_paper.pdf (accessed 11 August, 2015).

Sturgeon, T.J. 2013. Global Value Chains and Economic Globalization - Towards a New Measurement Framework. Report to Eurostat. Available at: http://ec.europa.eu/ eurostat/documents/54610/4463793/Sturgeon-report-Eurostat (accessed 6 May, 2014).

Talberth, J., C. Cobb, and N. Slattery. 2007. "The Genuine Progress Indicator 2006 A Tool for Sustainable Development." Redefining Progress, Oakland, CA. Available at: http://rprogress.org/publications/2007/GPI\%202006.pdf (accessed 11 February, 2016).

Taleb, N.N. 2007. The Black Swan - The Impact of the Highly Improbable. London: Allen Lane.

The Economist. 2016. “The Trouble with GDP.” 30 April 2016. Available at: http://www. economist.com/news/briefing/21697845-gross-domestic-product-gdp-increasinglypoor-measure-prosperity-it-not-even (accessed 9 September, 2016).

United Nations. 2012. "Secretary-General, in Message to Meeting on 'Happiness and Well-being' Calls for 'Rio+20' Outcome that Measures More than Gross National Income.” SG/SM/14204, Department of Public Information, New York, 2 April 2012. Available at: http://www.un.org/News/Press/docs/2012/sgsm14204.doc.htm (accessed 26 September, 2016).

United Nations. 2014. Resolution adopted by the General Assembly on 29 January 2014 - Fundamental Principles of Official Statistics, General Assembly, A/RES/68/261. Available at: http://unstats.un.org/unsd/dnss/gp/FP-New-E.pdf (accessed 26 September, 2016).

United Nations. 2014. System of Environmental-Economic Accounting 2012 Experimental Ecosystem Accounting. New York: United Nations. Available at: 
http://unstats.un.org/unsd/envaccounting/seeaRev/eea_final_en.pdf (accessed 26 September, 2016).

United Nations Conference on Trade and Development. 2005. 'Transnational Corporations: More - yet more - on Globalisation, by J.H. Dunning', Vol. 14, No. 2, August 2005. UNCTAD/ITE/IIT/2005/5. Available at: http://unctad.org/en/Docs/iteiit20055a5_en.pdf (accessed 26 September, 2016).

United Nations Conference on Trade and Development. 2008. Globalisation for Development: The International Trade Perspective. Available at: http://unctad.org/en/ Docs/ditc20071_en.pdf (accessed 26 September, 2016).

United Nations Conference on Trade and Development. 2012. The Paradox of FinanceDriven Globalisation. Policy Brief No. 1, 2012. Available at: http://unctad.org/en/Docs/ uxiiipb2012d1_en.pdf (accessed 26 September, 2016).

United Nations Conference on Trade and Development. 2015. Trade and Development Report, 2015 - Making the international financial architecture work for development. Available at: http://unctad.org/en/PublicationsLibrary/tdr2015_en.pdf (accessed 26 September, 2016).

United Nations Economic Commission for Europe. 2009a. "A Guide to Writing Stories about Numbers: Part 1 - Making Data Meaningful.” Geneva: United Nations. Available at: http://www.unece.org/fileadmin/DAM/stats/documents/writing/MDM_Part1_ English.pdf. (accessed 26 September, 2016).

United Nations Economic Commission for Europe. 2009b. "A Guide to Presenting Statistics: Part 2 - Making Data Meaningful.” Geneva: United Nations. Available at: http://www.unece.org/fileadmin/DAM/stats/documents/writing/MDM_Part2_English. pdf (accessed 26 September, 2016).

United Nations Economic Commission for Europe. 2011. "A Guide to Communicating with the Media: Part 3 - Making Data Meaningful.” Geneva: United Nations. Available at: http://www.unece.org/fileadmin/DAM/stats/documents/writing/MDM_Part3_ English_Print.pdf (accessed 26 September, 2016).

United Nations Economic Commission for Europe. 2012. "Guide on the Impact of Globalization on National Accounts.” Geneva: United Nations. Available at: http:// www.unece.org/fileadmin/DAM/stats/publications/Guide_on_Impact_of_globalization_ on_national_accounts_web_.pdf (accessed 26 September, 2016).

United Nations Economic Commission for Europe. 2012b. "A Guide to Improving Statistical Literacy: Part 4 - Making Data Meaningful." Geneva: United Nations. Available at: http://www.unece.org/fileadmin/DAM/stats/documents/writing/ Making_Data_Meaningful_Part_4_for_Web.pdf (accessed 26 September, 2016).

United Nations Economic Commission for Europe. 2013. "What does 'Big Data' mean for Official Statistics?" Paper presented by the Task Team established by the High-Level Group for the Modernisation of Statistical Production and Services. Available at: http:// www1.unece.org/stat/platform/pages/viewpage.action?pageId $=77170614$ (accessed 26 September, 2016).

United Nations Statistical Commission 2016. "Report of the Inter-Agency and Expert Group on Sustainable Development Goal Indicators - Note by the Secretary-General" presented to the $47^{\text {th }}$ Session of the UNSC, March 8-11, 2016, New York. Doc 
E/CN.3/2016/2/Rev.1. Available at: http://unstats.un.org/unsd/statcom/47th-session/ documents/2016-2-IAEG-SDGs-Rev1-E.pdf. (accessed 30 March, 2016).

United Nations Statistics Division. 2009. "System of National Accounts 2008." New York: United Nations. Available at: http://unstats.un.org/unsd/nationalaccount/docs/ SNA2008.pdf (accessed 26 September, 2016).

United Nations Statistics Division. 2010. “Tourism Satellite Account: Recommended Methodological Framework 2008." Studies in Methods, Series F, No. 80/Rev.1. New York: United Nations.

United Nations Statistical Commission. 2016. Report of the Inter-Agency and Expert Group on Sustainable Development Goal Indicators, 47 ${ }^{\text {th }}$ Session, 8-11 March, 2016. Dec Ref: E/CN.3/2016/2/Rev.1. Available at: http://unstats.un.org/unsd/statcom/ 47th-session/documents/2016-2-IAEG-SDGs-Rev1-E.pdf (accessed 26 September, 2016).

Vale, S. 2012. “The Data Deluge: What does it mean for official Statistics?" Paper presented at the $2^{\text {nd }}$ CSO Administrative Data Seminar, Dublin Castle, 29 September 2011. Available at: http://www.cso.ie/en/newsandevents/eventsconferencesseminars/ administrativedataseminars/2ndadministrativedataseminar/ (accessed 21 February, 2014).

Vale, S. 2013. "Fostering Interoperability in Official Statistics: Common Statistical Production Architecture." Posted on UNECE Statistics/MSIS Wiki on 12 February 2013. Available at: www1.unece.org/stat/platform/display/msis/2013/02/12/Plug + and + Play + project + launched (accessed 26 September, 2016).

Yergin, D. 2012. The Quest - Energy, Security and the Remaking of the Modern World. London: Penguin Books.

Received September 2014

Revised March 2016

Accepted August 2016 